\title{
Benthic metabolism and nitrogen dynamics in a sub- tropical coastal lagoon: Microphytobenthos stimulate nitrification and nitrate reduction through photosynthetic oxygen evolution
}

\author{
Ryan J.K. Dunn, ${ }^{\mathrm{a}, 1, *}$, David T. Welsh ${ }^{\mathrm{b}}$, Mark A. Jordan ${ }^{\mathrm{b}}$, Nathan J. Waltham ${ }^{\mathrm{c}, 2}$, \\ Charles J. Lemckert ${ }^{\mathrm{a}}$, Peter R. Teasdale ${ }^{\mathrm{b}}$
}

a Griffith School of Engineering, Griffith University, Gold Coast Campus, Griffith University, Queensland, 4222, Australia

b Environmental Futures Centre, Gold Coast Campus, Griffith University, Queensland, 4222, Australia

c Catchment Management Unit, Gold Coast City Council, PMB 5042 Gold Coast Mail Centre, Queensland 9729, Australia

* Corresponding author. Tel: +61 755741 112; Fax: +61 755741 113; email: rdunn@apasa.com.au

1 Present address: Asia-Pacific ASA Pty. Ltd. P.O. Box 1679 Surfers Paradise, Queensland, 4217, Australia

2 Present address: Centre for Tropical Water and Aquatic Ecosystem Research (TropWATER), James Cook University, Queensland, 4811, Australia

keywords: benthic fluxes; denitrification; dissimilatory nitrate reduction to ammonium (DNRA); microphytobenthos; southern Moreton Bay 


\begin{abstract}
Benthic oxygen and nutrient fluxes, and rates of nitrate reduction, were determined seasonally under light and dark conditions at four sites within a sub-tropical coastal lagoon (Coombabah Lake, Australia). Sediments at all sites were strongly heterotrophic acting as strong oxygen sinks and sources of dissolved inorganic nitrogen (DIN) in all seasons during both light and dark incubations. Sediment oxygen demand (SOD) and DIN effluxes were greatest during summer, but showed only a relatively small degree of seasonal variation. In contrast, there was a strong spatial trend in SOD and DIN effluxes, which were consistently greater at the sites with fine grained compared to the coarser sediments. Microphytobenthos (MPB) directly influenced SOD and DIN effluxes, with lower SOD and DIN effluxes measured during all light incubations. Strong correlations were found between sediment chlorophyll- $a$ content and light-dark shifts in oxygen and ammonium fluxes $\left(\Delta \mathrm{O}_{2}\right.$ and $\left.\Delta \mathrm{NH}_{4}{ }^{+}\right)$, and between $\Delta \mathrm{O}_{2}$ and $\Delta \mathrm{NH}_{4}{ }^{+}$. Rates of total nitrate reduction were relatively low ranging from 3 to $26 \mu \mathrm{mol} \mathrm{N} \mathrm{m} \mathrm{N}^{-2} \mathrm{~h}^{-1}$ and exhibited only minor seasonal variations. Dissimilatory nitrate reduction to ammonium (DNRA) was the dominant pathway for nitrate reduction, accounting for on average, 65 and $68 \%$ of total nitrate reduction during light and dark incubations, respectively. Nitrification was the dominant source of nitrate fuelling nitrate reduction processes, accounting for approximately $90 \%$ of total nitrate supply. In contrast to typical MPB colonised sediments, rates of nitrification and, as a consequence, nitrate reduction rates were consistently stimulated in the light, indicating that MPB primarily influenced these processes through photosynthetic oxygen evolution rather than through competition for inorganic N-species.
\end{abstract}




\section{Introduction}

Estuaries are dynamic ecosystems situated at the interface between marine and terrestrial environments and therefore sedimentary organic matter pools within estuaries are commonly the result of both autochthonous production and allochthonous inputs (Bouillon et al., 2003; Dunn et al., 2008). Surface sediments in estuarine environments are significant sites for the accumulation of organic matter, intense microbial metabolism, and nutrient cycling. The sediment-water interface (SWI) is a dynamic zone, characterised by steep biological and physico-chemical gradients that foster changes in the nature of the deposited organic matter (Berner, 1980). The biogeochemistry of marine sediments is influenced by a number of competing and interacting physical, biological, and chemical factors (Risgaard-Petersen et al., 1994; Sundbäck et al., 2000; Sakamaki et al., 2006) often resulting in significant spatial and temporal variations in nutrient cycling. The distributions of benthic infauna and microphytobenthos often exhibit a high degree of spatial heterogeneity (Sandulli and Pinckney, 1999; Spilmont et al., 2011) creating shifting, complex distributions of porewater solutes and microbial dynamics within the surface sediments (Wenzhofer and Glud, 2004; Robertson et al., 2008, 2009; Pagès et al., 2011). Similarly, plant and animal communities exert major influences on sediment nutrient exchanges and dynamics (Rysgaard et al., 1995; Sundbäck et al., 2000; Eyre et al., 2011; Welsh et al., 2000).

In recent decades anthropogenic activities have delivered increased nitrogen loads to estuaries often leading to eutrophication (Vitousek et al., 1997). Therefore, it is important to understand the processes involved in the recycling and removal of $\mathrm{N}$ species in these systems. Surface sediments play an important role in the microbially mediated transformations of nitrogen in shallow marine systems (Fenchel et al., 1998) and, as a result, consideration has been given to their role in regulating nitrogen dynamics. Sediment denitrification has been shown to eliminate 
as much as $60 \%$ of terrestrial nitrogen loads to marine systems by converting it to gaseous endproducts (Barnes and Owens, 1998; Berelson et al., 1998; Thornton et al., 2007). However, dissimilatory nitrate reduction to ammonium (DNRA) competes with denitrification for $\mathrm{NO}_{\mathrm{X}}$, potentially limiting $\mathrm{N}$ losses from the marine environment. DNRA can be a significant $\mathrm{N}$-cycling process, especially in metabolically active, organically enriched environments (Tiedje, 1988; Christensen et al., 2000; Nizzoli et al., 2006) and may be the dominant pathway for nitrate reduction in tropical estuaries (Dong et al., 2011; Molnar et al., 2012). In contrast to denitrification, DNRA recycles bioavailable $\mathrm{N}$ through the reduction of $\mathrm{NO}_{\mathrm{X}}$ to ammonium $\left(\mathrm{NH}_{4}{ }^{+}\right)$. Thus, the rates and relative contributions of denitrification and DNRA to overall nitrate reduction rates have profound implications for the fate of nitrogen as they influence the loss/retention of $\mathrm{N}$ within the system. Whilst, denitrification and its role in $\mathrm{N}$-dynamics has been intensively studied, only a relatively small proportion of these studies have also investigated the role of DNRA (Gardner et al., 2006; Nizzoli et al., 2006; Thornton et al., 2007; Dunn et al., 2009; Dong et al., 2011). Moreover, most studies of N-dynamics and particularly nitrate reduction processes have focussed on temperate estuaries of the northern hemisphere and much less is known about the N-dynamics of tropical and sub-tropical estuaries. Obvious differences between these geographical regions (seasonal temperature ranges and rainfall patterns) would conceivably lead to differences in the delivery of organic matter and inorganic nutrients from terrestrial sources, and their fate within the downstream estuary.

The aims of this study were to quantify spatial and temporal patterns in surface sediment oxygen and inorganic nitrogen exchanges, major nitrogen cycle processes (nitrification, denitrification and DNRA) and the role of microphytobenthos (MPB) in regulating nitrogen cycling in a southern hemisphere sub-tropical estuarine lagoon (Coombabah Lake, Australia). 


\section{Materials and methods}

\subsection{Site description}

Coombabah Lake (Fig. 1) is a shallow, sub-tropical, partially urbanised coastal lagoon within southern Moreton Bay, Australia. The lagoon is mangrove dominated, subject to a mixed semidiurnal tidal regime and hydrologically open to the Gold Coast Broadwater via Coombabah creek (Knight et al., 2008; Ali et al., 2010). The lagoon is characterised by a relatively flat topography with water depths generally 0 to $\sim 1 \mathrm{~m}$ with large portions of the lagoon sediments exposed at low tide (Dunn et al., 2008). Fine-grained sediments dominate the southern part of the lagoon with a gradient towards sands at the northern end. Seagrass is absent throughout the lagoon. The region experiences warm/hot humid summers (December-February) influenced by monsoonal trade winds, with thunderstorms resulting in intense rainfall events. In contrast, the mild winters (JuneAugust) are dominated by sub-tropical high pressure belt systems and low rainfall.

\subsection{Sample sites and study design}

Sediments were collected at four sites (Fig. 1) representing differing: (i) sediment types, (ii) organic matter sources, (iii) nutrient contents, (iv) faunal communities and (v) hydrology (Dunn et al., 2007a, 2008; Knight et al., 2008; Ali et al., 2010). Six cores were collected from each site in winter and spring (September-November) 2006, and summer and autumn (March-May) 2007 for the determination of oxygen and dissolved inorganic nitrogen (DIN) fluxes across the SWI and nitrification, denitrification and DNRA rates under light and dark conditions. Three additional cores were collected at each site for the characterisation of physico-chemical surface sediment parameters. 


\subsection{Sediment and water collection}

Undisturbed sediment cores ( $\sim 12 \mathrm{~cm}$ sediment depth) for flux and process rate determinations were manually collected at low tide using plexiglass core tubes $(20 \mathrm{~cm}$ internal diameter $\times 33 \mathrm{~cm}$ length) and transported to the laboratory within $2 \mathrm{~h}$. Water for core incubations was collected using deionised water washed plastic containers during the following flood tide and triplicate samples retained to determine ambient DIN and chlorophyll- $a$ (chl- $a$ ) concentrations.

Sediments collected for the determination of biogeochemical parameters (grain size distribution, $\mathrm{LOI}_{550}$, as a proxy for organic matter content, and bioavailable ammonium $\left(\mathrm{NH}_{4}{ }^{+}\right.$bio, porewater + exchangeable $\left.\mathrm{NH}_{4}{ }^{+}\right)$) were collected using PVC core tubes $(5 \mathrm{~cm}$ internal diameter $\times$ $40 \mathrm{~cm}$ length) and immediately sliced into 6 depth horizons (0-1, 1-2, 2-4, 4-6, 6-10 and 10-15 $\mathrm{cm})$ and stored in the dark $\left(<4^{\circ} \mathrm{C}\right)$ until being returned to the laboratory within $2 \mathrm{~h}$. Concentrations of chl- $a$ were determined for the surface $0-1 \mathrm{~cm}$ sediment horizon only.

\subsection{Determination of sediment-water column oxygen and nutrient fluxes}

Following collection, triplicate cores from each site were transferred into light and dark holding tanks (220 1) containing aerated site water. An aquarium pump was attached to the inner wall of each core and each core was aerated during the $\sim 12 \mathrm{~h}$ equilibration period. Measured seasonal in situ illumination and temperature were replicated during core equilibration and incubation $\left(16,20,24\right.$, and $20^{\circ} \mathrm{C}$ and $\sim 80,100,120$ and $100 \mu \mathrm{mol}$ photons $\mathrm{m}^{-2} \mathrm{~s}^{-1}$ at the sediment surface for winter, spring, summer and autumn incubations, respectively). Following equilibration, the light and dark conditions were swapped, the water within the holding tanks replaced by $\sim 40 \%$ new site water and the cores were re-equilibrated under the new conditions for $\sim 2 \mathrm{~h}$.

To initiate incubations, the water level in the holding tanks was lowered to below the core 
rims. Initial water samples for $\mathrm{O}_{2}$ and DIN were collected, the cores closed using floating plastic lids to prevent gaseous exchange and incubated for $\sim 1.5 \mathrm{~h}$. At the end of the incubation, the aquarium pumps were turned off, the floating lids removed and final time water samples collected. Flux rates $\left(\mu \mathrm{mol} \mathrm{m} \mathrm{m}^{-2} \mathrm{~h}^{-1}\right)$ were calculated from the change in the water column concentrations of each solute (Welsh et al., 2000).

\subsection{Determination of rates of denitrification and DNRA}

Following flux incubations, aeration was restored, the water level in the holding tanks was raised to above the core tops and the cores were re-equilibrate for $\sim 2.5 \mathrm{~h}$ prior to determinations of nitrate reduction rates by the isotope pairing technique (IPT), as modified for simultaneous determination of denitrification and DNRA (Risgaard-Petersen and Rysgaard, 1995; Nizzoli et al., 2006). Briefly, cores were prepared for incubation as described for flux determinations and an initial water sample collected from each core for determination of ambient $\mathrm{NO}_{3}{ }^{-}$concentrations. Sufficient $30 \mathrm{mM} 99.9$ atom $\%{ }^{15} \mathrm{~N}^{-N_{3}}{ }^{-}\left(\right.$ISOTEC $\left.^{\mathrm{TM}}\right)$ solution was added to each core to give a final concentration of $\sim 30 \mu \mathrm{M}$ in the overlying water. The water column was mixed and a water sample for $\mathrm{NO}_{3}{ }^{-}$was taken after $\sim 10$ mins to enable calculation of the actual ${ }^{15} \mathrm{~N}_{-} \mathrm{NO}_{3}$ addition by difference. Cores were closed using floating plexiglass lids and incubated as described for flux determinations. Incubation times $(<2 \mathrm{~h})$ were calculated from the sediment oxygen demand (SOD) to ensure that the final $\mathrm{O}_{2}$ concentration remained above $80 \%$ of the initial value, a prerequisite of the IPT (Nielsen, 1992). At the end of the incubation the aquarium pumps were stopped, the floating lids removed and a sub-core $(2.5 \mathrm{~cm}$ internal diameter $\times 33 \mathrm{~cm}$ length $)$ was inserted to the base of each of the incubation cores. Microbial activity in the bulk sediment was inhibited by addition of $5 \mathrm{ml} 50 \% \mathrm{w} / \mathrm{VnCl}_{2}$ to the water outside the sub-core. The sub-core 
including the overlying water was withdrawn and emptied into a sample bottle containing sufficient powdered $\mathrm{KCl}$ to give a final concentration of $\sim 2 \mathrm{~mol}^{-1}$ and vigorously shaken. The sediment- $\mathrm{KCl}$ slurries were stored $<4{ }^{\circ} \mathrm{C}$ and shaken intermittently over a 24 hour period to extract the $\mathrm{NH}_{4}{ }^{+}$bio pool. Sub-samples of the sediment- $\mathrm{KCl}$ slurry were filtered (GF/F, Whatman) and stored frozen awaiting analysis of the $\mathrm{NH}_{4}{ }^{+}$concentration and the ${ }^{15} \mathrm{~N}$-enrichment of the $\mathrm{NH}_{4}{ }^{+}$pool. The remaining sediment within the cores was gently slurried to mix the dissolved $\mathrm{N}_{2}$ pools in the porewater and overlying water. Following a brief settling period (1-2 min), a sample of the slurry was transferred to a gas-tight, $12 \mathrm{ml}$ glass vial (Exetainer, Labco), $150 \mu 150 \% \mathrm{w} / \mathrm{v}$ $\mathrm{ZnCl}_{2}$ added and the samples stored $<4{ }^{\circ} \mathrm{C}$ awaiting determination of the dissolved $\mathrm{N}_{2}$ pool and its isotopic composition. Total denitrification $\left(D_{14}\right)$, coupled nitrification-denitrification $\left(D_{n}\right)$ and denitrification of $\mathrm{NO}_{3}{ }^{-}$diffusing from the overlying water $\left(\mathrm{D}_{\mathrm{w}}\right)$ rates were calculated according to Nielsen (1992). DNRA rates based on water column $\mathrm{NO}_{3}{ }^{-}\left(\mathrm{DNRA}_{\mathrm{w}}\right)$ were calculated from the ${ }^{15} \mathrm{~N}$-enrichment of the water column $\mathrm{NO}_{3}{ }^{-}$and $\mathrm{NH}_{4}{ }^{+}$bio pools (Risgaard-Petersen and Rysgaard, 1995). Rates of DNRA coupled to nitrification $\left(\mathrm{DNRA}_{\mathrm{n}}\right)$ were estimated from $\mathrm{DNRA}_{\mathrm{w}}$ and the ratio between $D_{n}$ and $D_{w}$ (Risgaard-Petersen and Rysgaard, 1995).

Anammox is recognised as an interference when using the IPT that can lead to overestimation of denitrification rates, as it also generates labelled $\mathrm{N}_{2}$ species following ${ }^{15} \mathrm{NO}_{3}{ }^{-}$additions (Risgaard-Petersen et al., 2003). However, in shallow water sediments anammox has been shown to be a minor source of $\mathrm{N}_{2}$ compared to denitrification (Dalsgaard et al., 2005; Burgin and Hamilton, 2007), especially in tropical systems (Dong et al., 2011). Therefore, we believe that our estimates of denitrification are valid, although it should be noted that the term denitrification as used here also includes a small portion of $\mathrm{N}_{2}$ via anammox. 


\subsection{Sample handling and analytical techniques}

Site water samples of $100 \mathrm{ml}$ were collected using acid washed, sample rinsed polyethylene bottles. DIN samples were immediately filtered through washed, pre-ashed GF/F filters (Whatman), transferred to $10 \mathrm{ml}$ sample rinsed tubes and frozen. Chlorophyll- $a$ samples were collected by filtering known volumes of water through pre-ashed GF/C filters (Whatman), which were stored frozen in foil wrapped glass vials. Concentrations of chl- $a$ were determined after acetone extraction according to Lorenzen (1967). Water column physico-chemical data were recorded on site using a multi-probe analyser (TPS 90-FLMV, TPS Pty. Ltd.). In situ light intensities were measured using a LI-COR radiation sensor (SA: LI-192SA quantum sensor) at a water depth of $\sim 15 \mathrm{~cm}$. For consistency, light intensity and water temperature were always measured at approximately midday $(12: 00 \mathrm{pm} \pm 1 \mathrm{~h})$.

During core incubations water samples were collected using acid washed, Milli-Q water rinsed $60 \mathrm{ml}$ plastic syringes and tubing. Samples for DIN were filtered (GF/F, Whatman) and stored frozen $\left(-20{ }^{\circ} \mathrm{C}\right)$. Dissolved $\mathrm{O}_{2}$ samples were carefully transferred to gas-tight, $12 \mathrm{ml}$ glass vials (Exetainer, Labco Ltd.) and fixed with $100 \mu 1$ of manganous sulfate and alkali-iodide-azide (APHA, 1999).

Concentrations of $\mathrm{NO}_{2}^{-}, \mathrm{NO}_{3}{ }^{-}$and $\mathrm{NH}_{4}{ }^{+}$were determined using an automated analyser (Easychem Plus, Systea Analytical Technologies). Milli-Q Element water and filtered low nutrient seawater were used for all sample preparation. Filtered seawater standards and references produced by the National Low Level Nutrient Collaborative Trials were used for quality assurance. Recoveries of all nutrients from the seawater references ranged between 90 and $104 \%$. Dissolved $\mathrm{O}_{2}$ concentrations were determined by Winkler titration with azide modification (APHA, 1999). Salinity was determined using a refractometer and water temperature using a

digital thermometer. Dissolved $\mathrm{N}_{2}$ concentrations and proportions of ${ }^{29} \mathrm{~N}_{2}$ and ${ }^{30} \mathrm{~N}_{2}$ and the ${ }^{15} \mathrm{~N}$ 
enrichment of sediment $\mathrm{NH}_{4}{ }^{+}$bio pool were determined at NERI, Silkeborg, Denmark as described by Risgaard-Petersen and Rysgaard (1995).

Sediment density was measured directly on known volumes of sediment, porosity after drying to constant weight and $\mathrm{LOI}_{550}$ as loss of dry weight after 1 hour at $550{ }^{\circ} \mathrm{C}$. Sediment grain size was determined by dry sieving and expressed as \% dry mass. Sediments for determination of chl$a$ contents were freeze dried, extracted in $10 \mathrm{~mL} 90 \%$ acetone for $24 \mathrm{~h}$ in the dark at $4{ }^{\circ} \mathrm{C}$ following Lorenzen (1967).

\subsection{Statistical analyses}

Results from triplicate analyses are presented as means \pm standard deviation. Correlations between physico-chemical sedimentary conditions, flux and nitrate reduction rates were analysed using Pearson correlation matrices (2-tailed, $\alpha=0.05)$. Spatial and temporal variations in fluxes and N-cycling processes were analysed using a three-way ANOVA (light condition, season and site fixed; interaction included). Homogeneity of variances was tested using box and whisker plots, before and after data transformation (Quinn and Keough 2002). Variances were best stabilised with a $\log (\mathrm{x})$ transformation. Significant differences in physico-chemical sediment parameters were also assessed using a three-way ANOVA (site, season, depth fixed; interaction included). Post hoc comparisons were performed using Tukey's HSD. All statistical analyses were performed using SPSS Windows (SPSS Inc., version 11.5.0).

\section{Results}

\subsection{Water column physico-chemical characteristics}

Water temperature varied from $18.4^{\circ} \mathrm{C}$ in winter to $25.7^{\circ} \mathrm{C}$ in summer and salinity between 
32.1 in spring and 33.6 in autumn (Table 1). Dissolved nutrient concentrations were relatively stable with DIN concentrations ranging between 40.9 (winter) and $56.4 \mu \mathrm{M}$ (summer), with $\mathrm{NH}_{4}{ }^{+}$ representing 73 to $84 \%$ of DIN. Water column chl- $a$ concentrations were low in all seasons varying between 1.1 and $1.8 \mu \mathrm{gl}^{-1}$ (Table 1 ).

\subsection{Sediment physico-chemical characteristics}

Northern lagoon sampling sites were characterised by sandier sediments with $250-500 \mu \mathrm{m}$ size fractions contributing $24.2 \pm 1.4 \%$ to $31.7 \pm 8.3 \%$ and $22.6 \pm 9.1 \%$ to $27.8 \pm 14.6 \%$ to the overall particle size distribution at sites 1 and 2, respectively. The fine sediment fraction, $<63$ $\mu \mathrm{m}$, was greatest at sites 3 and 4 contributing $4.1 \pm 1.7 \%$ to $6.4 \pm 2.6 \%$ to the overall particle size distribution, respectively. Sediments were characterised by high organic matter contents with a depth integrated average lagoon-wide $\mathrm{LOI}_{550}$ of $3.87 \pm 2.18 \%$. Depth integrated $\mathrm{LOI}_{550}$ values at the northern sites ( 1 and 2 ) were $1.70 \pm 0.40$ and $3.32 \pm 1.48 \%$ respectively, and significantly lower $(p<0.001)$ compared to the muddy southern sites $3(5.20 \pm 1.93 \%)$ and $4(5.25 \pm 1.38 \%)$. Combined annual depth integrated mean sediment $\mathrm{NH}_{4}{ }^{+}$bio concentrations ranged from $74.4 \pm$ 46.4 (site 1) to $323.4 \pm 196.6$ (site 4 ) nmol g dry $\mathrm{wt}^{-1}$ and were significantly greater $(p<0.001$ ) at the muddy compared to sandy sampling sites. $\mathrm{NH}_{4}{ }_{\text {bio }}$ concentrations were highest during summer and autumn at all sample sites with significant seasonal variations observed $(p<0.001)$.

Sediment chl- $a$ content varied seasonally at all sites (Fig. 2) with the highest concentrations measured in summer and autumn. Chl- $a$ concentrations at site 1 were characterised by the largest seasonal range, ranging from 54.5 (spring) to 2722.7 (autumn) $\mu \mathrm{g}$ chl- $a \mathrm{~m}^{2}$. The lowest annual mean chl- $a$ concentration (653.5 $\mu \mathrm{g}$ chl- $a \mathrm{~m}^{2}$ ) occurred at site 3 , where seasonality was also less obvious. Seasonal chl- $a$ concentrations at site 4 were significantly greater $(p<0.001)$ than other 
sample sites and were characterised by a summer mean of $3267.2 \mu \mathrm{g}$ chl- $a \mathrm{~m}^{2}$ and an annual mean concentration of $1651.8 \mu \mathrm{g}$ chl- $a \mathrm{~m}^{2}$.

\subsection{Sediment-water column oxygen and DIN fluxes}

Sediments at all sites were strongly heterotrophic and characterised by oxygen consumption, during both light and dark incubations (Fig. 3a and 3b). Mean dark $\mathrm{O}_{2}$ fluxes ranged from -4736 \pm 1207 to $-1435 \pm 279 \mu \mathrm{mol} \mathrm{m} \mathrm{m}^{-2} \mathrm{~h}^{-1}$ with dark SOD being significantly larger than during light conditions (Table 2). Dark SOD showed significant seasonal variations at all sites with highest consumption rates measured during the summer period. SOD was also significantly greater in the organic matter rich sediments of sites 3 and 4 compared to the sandy sediments of sites 1 and 2 in all seasons. Dark SOD was significantly correlated with sediment organic matter content $\left(\mathrm{LOI}_{550}\right)$, chl- $a$ concentration and all DIN fluxes (Table 3). Rates of gross benthic primary productivity $\left(\Delta \mathrm{O}_{2}=\right.$ difference between the light and dark $\mathrm{O}_{2}$ fluxes $)$ demonstrated greater spatial and temporal variation, ranging from 8 to $3868 \mu \mathrm{mol} \mathrm{m}^{-2} \mathrm{~h}^{-1}$ (Fig. 3c) with significantly greater $(p$ $<0.001$ ) differences at southern sites 3 and 4. Lowest rates of gross productivity occurred during winter with a lagoon-wide mean rate of $746 \pm 807 \mu \mathrm{mol} \mathrm{O} \mathrm{m}^{-2} \mathrm{~h}^{-1}$ compared to the summer maximum of $2282 \pm 1586 \mu \mathrm{mol} \mathrm{O} \mathrm{m}^{-2} \mathrm{~h}^{-1}$.

Sediments at all sites were sources of DIN, $\mathrm{NH}_{4}{ }^{+}$and $\mathrm{NO}_{\mathrm{X}}$ to the water column during both light and dark (Fig. 4) incubations. DIN effluxes ranged from 69 to 211 , and 79 to $390 \mu \mathrm{mol} \mathrm{m}{ }^{-2}$ $\mathrm{h}^{-1}$ under light and dark conditions respectively, with the highest effluxes occurring during summer. DIN effluxes demonstrated significant differences between light and dark conditions, seasons and sites (Table 2). A significant interaction between season and sampling site was also observed with the greatest effluxes measured at the muddier sampling sites during summer (Fig. 
4). Ammonium was the dominant component of the DIN effluxes representing 33 to $79 \%$ (mean 64\%), and 57 to $88 \%$ (mean $76 \%$ ) of the light and dark effluxes respectively, with the highest contributions occurring during summer.

Overall, $\mathrm{NH}_{4}{ }^{+}$effluxes showed similar significant spatio-temporal variations to those observed for DIN with maximal effluxes occurring in summer under both light and dark conditions, and effluxes being significantly greater in all seasons at the southern muddy sites 3 and 4 compared to sites 1 and 2 (Fig. 4). In contrast to DIN and $\mathrm{NH}_{4}{ }^{+}$effluxes, sediment $\mathrm{NO}_{\mathrm{X}}$ effluxes showed only a low and insignificant degree of seasonal variation, and were not significantly influenced by light conditions (Table 2). However, $\mathrm{NO}_{\mathrm{X}}$ effluxes did vary significantly between sites with greater effluxes measured at sites 3 and 4 in the muddier region of the lagoon (Fig. 4). Nitrate was the dominant component of the $\mathrm{NO}_{\mathrm{X}}$ effluxes at all sites in all seasons, representing 67 to $93 \%$ (mean $78 \%$ ) and 68 to $84 \%$ (mean $77 \%$ ) of the $\mathrm{NO}_{\mathrm{X}}$ effluxes during light and dark incubations, respectively. Significant correlations between inorganic nutrient fluxes, chl- $a$ and organic matter content is shown in Table 4.

\subsection{Nitrification and $\mathrm{NO}_{3}{ }^{-}$reduction processes}

Total $\mathrm{NO}_{3}{ }^{-}$reduction rates were relatively low at all sites under both light and dark conditions, ranging from 3 to $26 \mu \mathrm{mol} \mathrm{N} \mathrm{m}{ }^{-2} \mathrm{~h}^{-1}$ (Fig. 5), but showed significant differences between sites and seasons (Table 5). Total $\mathrm{NO}_{3}{ }^{-}$reduction rates were also significantly stimulated during light compared to dark incubations.

DNRA was the dominant pathway for nitrate reduction under both light and dark conditions, at all sites, in all seasons with the exception of site 2 in summer and autumn where denitrification dominated during light, but not dark incubations (Fig. 5). Overall, DNRA accounted for $65.3 \pm$ $19.6 \%$ and $68.2 \pm 12.1 \%$ of annual nitrate reduction during light and dark conditions, 
respectively. Mean DNRA rates varied from 1.4 to 25.4 , and 1.8 to $16.9 \mu \mathrm{mol} \mathrm{N} \mathrm{m} \mathrm{h}^{-1}$ during light and dark incubations, and were significantly greater during light compared to dark incubations (Table 5). Denitrification was a less important pathway for nitrate reduction than DNRA with mean rates varying from 1.1 to 5.7 , and 0.5 to $3.5 \mu \mathrm{mol} \mathrm{N} \mathrm{m} \mathrm{m}^{-1}$ during light and dark incubations respectively.

Nitrification was the predominant source of nitrate fuelling nitrate reduction under both light and dark conditions at all sites in all seasons with $D_{n}+D_{N R A_{n}}$ accounting for most (average $87.2 \pm 10.73 \%$ ) of total nitrate reduction. Nitrification rates under dark conditions when MPB can be assumed not to be assimilating $\mathrm{NO}_{\mathrm{X}}$ can be calculated by mass balance, as nitrification $=$ $\Sigma \mathrm{NO}_{\mathrm{X}}$ flux + total nitrate reduction. Based on this formula, annual mean dark nitrification rates were $36.9 \pm 8.1,39.4 \pm 15.4,42.0 \pm 12.8,51.6 \pm 18.2 \mu \mathrm{mol} \mathrm{m}^{-2} \mathrm{~h}^{-1}$ for sites 1 to 4 , respectively. However, as during all light incubations there were significant $\mathrm{NH}_{4}{ }^{+}$effluxes, it can also be assumed that rates of $\mathrm{NO}_{\mathrm{X}}$ assimilation by MPB were also negligible during these incubations and the same calculation can be applied. This yields annual mean light nitrification rates of 41.3 \pm 8.0, 37.2 $\pm 11.3,46.7 \pm 12.4$ and $60.9 \pm 19.7 \mu \mathrm{mol} \mathrm{m} \mathrm{m}^{-2} \mathrm{~h}^{-1}$ for sites 1 to 4 , respectively. Nitrification rates showed significant seasonal differences (Table 5) and were significantly greater at the muddier sites 3 and 4 compared to the sandier sites 1 and 2 . Although estimated nitrification rates at all sites showed a trend of being higher under light compared to dark conditions, these increases were not significant (Table 5). Maximal nitrification rates occurred during autumn with lagoon-wide mean rates of $55.8 \pm 18.2$ and $49.9 \pm 16.0 \mu \mathrm{mol} \mathrm{m} \mathrm{m}^{-2} \mathrm{~h}^{-1}$ during light and dark incubations.

The degree of coupling between nitrification and nitrate reduction processes can be calculated from the measured rates of $D_{n}$ and $D_{N R A}$, and the estimates of nitrification rates $\left[\left(D_{n}+\right.\right.$ 
$\mathrm{DNRA}_{\mathrm{n}} /$ nitrification $\left.) \times 100\right]$. Annual mean values for the coupling between nitrate reduction and nitrification were $21.8 \pm 6.4,14.4 \pm 4.3,11.7 \pm 2.8$ and $22.5 \pm 12.4 \%$ during light incubations, and $18.3 \pm 2.8,11.1 \pm 4.6,9.9 \pm 3.1$ and $15.2 \pm 10.1 \%$ during dark incubations, for sites 1 to 4 , respectively. The degree of coupling between nitrification and nitrate reduction was significantly enhanced during light incubations and was significantly greater at the muddier sites 3 and 4, but did not demonstrate any significant seasonal variations (Table 5).

Benthic denitrification efficiencies [(denitrification/DIN efflux + denitrification $) \times 100]$ were significantly different between light/dark conditions, seasons and sample sites (Table 5). Efficiencies were generally low at all sites in all seasons ranging between 0.2 and $4.0 \%$. Seasonal lagoon-wide mean denitrification efficiencies ranged between $1.0 \pm 0.4$ and $2.5 \pm 1.4 \%$, with the highest efficiencies occurring during autumn. Denitrification efficiencies at site 1 and $2(2.2 \pm$ $1.6 \%)$ were significantly greater than those at sites 3 and $4(1.0 \pm 0.8 \%)$.

\section{Discussion}

\subsection{Benthic metabolism and nutrient fluxes}

The lagoon sediments were consistent strong sinks for oxygen during both light and dark incubations. This sustained oxygen consumption may impact water column $\mathrm{O}_{2}$ concentrations, contributing to the low DO saturation previously recorded in the lagoon (Waltham et al., 2002; Dunn et al., 2007b). Based on the trophic oxygen status index of Viaroli and Christian (2003), which provides a simple portrayal of oxygen processing in aquatic systems, the lagoon was classified as net heterotrophic at all four sampling sites during all seasons. The trophic status of aquatic systems essentially represents the difference between primary production and community respiration (Viaroli and Christian, 2003; Viaroli et al., 2004). Within shallow-water systems such 
as Coombabah Lake, where seagrass is absent, this is largely determined by the photosynthetic activity of MPB (Engelsen et al., 2008). MPB were present at all four study sites, as indicated by the sediment chl- $a$ concentrations and reduced sediment oxygen consumption during light incubations. However, rates of photosynthetic oxygen production were small in comparison to community respiration rates and consequently net oxygen fluxes remained negative during light incubations. This reflects the high inputs of organic matter to the lagoon sediments from external sources (Dunn et al., 2008), which drive high SOD and the high turbidity of the water column (Dunn et al., 2007b), which limits light availability for photosynthesis at the sediment surface during tidal immersion. Although higher production is likely to occur during emersion as a result of the improved light environment (Spilmont et al., 2007). Lower seasonal variations in temperature and more stable inputs of organic matter from perennial vegetation (e.g. mangroves) within the lagoon may contribute to this stability in benthic metabolism. In comparison, large temperature changes and the occurrence of ephemeral primary producers within temperate systems often cause strong seasonal variations in oxygen dynamics, as periods of high photoautotrophic oxygen production and accumulation of organic matter, are followed by predominantly heterotrophic phases, when the plants die and are decomposed. This can result in dramatic seasonal variations in water column oxygen concentrations, spanning from supersaturation to anoxia (Viaroli and Christian, 2003).

The strongly heterotrophic nature of the sediments drove sustained effluxes of DIN during all seasons at all sites, under both light and dark conditions. The relative proportions of the $\mathrm{N}$ species effluxing from the sediments were quite consistent with $\mathrm{NH}_{4}{ }^{+}$dominating. This has implications for the trophic status of the lagoon, as nitrogen returned to the overlying waters as $\mathrm{NH}_{4}{ }^{+}$may stimulate phytoplankton productivity, resulting in the delivery of additional labile 
organic matter to the sediments to fuel SOD (Eyre and Ferguson, 2002 and references therein). DIN effluxes exhibited clear seasonality with greatest effluxes occurring during summer.

Lower DIN effluxes under light compared to dark conditions for sediments colonized by MPB have frequently been observed and attributed to direct uptake of nutrients by the MPB to meet their growth requirements (Sundbäck et al., 1991; Risgaard-Petersen et al., 1994; Sundbäck et al., 2000). Although the strongly heterotrophic nature of the studied sediments suggest a relatively less active microalgal community, SOD and DIN fluxes during light incubations were reduced by on average $43.4 \pm 31.2$ and $34.9 \pm 30.5 \%(n=48)$, respectively, in comparison to the corresponding dark incubations. These reductions were greatest during summer/autumn, coinciding with maximal sediment chl- $a$ contents, and significantly larger in the muddier southern lagoon sediments, which consistently had higher sediment chl- $a$ contents than the sandy northern sites.

Distributions of MPB often exhibit a high degree of seasonal and spatial heterogeneity within estuaries (Sandulli and Pinckney, 1999; Spilmont et al., 2011), which can create local variations in benthic oxygen and nutrient dynamics (Bartoli et al., 2003). The regulatory influence of shifting densities or photosynthetic activities of MPB on solute fluxes can be studied by plotting the light/dark shift in the solute flux ( $\Delta$ solute) against chl- $a$ concentrations or $\Delta \mathrm{O}_{2}$ fluxes, as a measure of photosynthetic activity (Sundbäck et al., 1991). At our sites, increases in $\Delta \mathrm{O}_{2}$ were significantly correlated with sediment chl- $a$ content (Fig. 6a). Significant correlations were also identified between $\Delta \mathrm{NH}_{4}{ }^{+}$and both chl- $a$ concentrations and $\Delta \mathrm{O}_{2}$ (Fig. $6 \mathrm{~b}$ and $6 \mathrm{c}$ ). Thus, although the sediments remained $\mathrm{O}_{2}$ sinks and DIN sources during light incubations, MPB still played a significant role in moderating these fluxes through photosynthetic oxygen evolution and coupled photoassimilation of inorganic nitrogen. 
The sustained efflux of DIN demonstrates that the lagoon sediments are a constant nutrient source to the overlying lagoon waters. Therefore, the lagoon is potentially a nutrient source for the downstream Coombabah Creek/Gold Coast Broadwater estuary. However, previously estimated nutrient transport rates showed no net export of nutrients from the lagoon and in fact suggested that Coombabah Creek was a source of nutrients for the lagoon over tidal cycles (Dunn et al., 2007b). Therefore, it appears that regenerated nutrients effluxing from the sediment are recycled within the lagoon and surrounding wetlands. Within the lagoon the fate of regenerated nutrients would be determined by photo-assimilation by MPB and phytoplankton communities, however, due to the turbid nature of the lagoon waters these nutrient sinks would be limited. It is more likely the case that the large areas of fringing mangroves and wetlands are the major nutrient sinks and these are in turn a major source of organic matter to the lagoon sediments (Dunn et al., 2008). The uptake of nutrients by higher plants is an effective means of ameliorating the impact of elevated nutrient concentrations entering receiving waters (Wong et al., 1997 and references therein) and constructed and natural mangroves have been used successfully as biological water treatment systems (Robertson and Phillips, 1995; Wong et al., 1997). In the case of Coombabah Lagoon, the clearing of fringing mangroves for ongoing urban development would be expected to impact negatively on the environmental quality and trophic status of not only the lagoon and the surrounding wetlands, but ultimately on the eutrophication status of the downstream Coombabah Creek/Gold Coast Broadwater estuary.

\subsection{Nitrification and nitrate reduction processes}

The efflux of $\mathrm{NO}_{\mathrm{X}}$ during all sediment incubations indicated that nitrification was an important process within the lagoon sediments. Although sediment nitrification rates are 
influenced by various parameters, of these the availability of oxygen and $\mathrm{NH}_{4}{ }^{+}$the electron acceptor and donor for chemoautotrophic ammonium oxidisers are of fundamental importance (Fenchel et al., 1998). The consistent stimulation of nitrification rates during the light incubations and the constant efflux of $\mathrm{NH}_{4}{ }^{+}$from the lagoon sediments, indicates oxygen availability was the primary factor regulating benthic nitrification rates within Coombabah Lake. This contrasts with studies of other MPB colonised sediments, where $\mathrm{NH}_{4}{ }^{+}$availability has been largely responsible for regulating nitrification rates, resulting in substantially lower rates of nitrification under light conditions despite the high availability of photosynthetically produced oxygen, due to competition between nitrifying bacteria and MPB for $\mathrm{NH}_{4}{ }^{+}$(e.g. Risgaard-Petersen et al., 1994).

Temporal variations in nitrate reduction rates were not characterised by the distinct seasonal patterns commonly recorded in temperate systems (e.g. Rysgaard et al., 1995; Norwicki et al., 1997; Hietanen and Kuparinen, 2008). Maximum or near maximum total $\mathrm{NO}_{3}{ }^{-}$reduction and denitrification rates generally occurred during summer/autumn, and minima mostly during winter, although the magnitude of these seasonal variations was relatively low. In contrast, in temperate northern hemisphere environments, seasonal variations are generally large, with increased, and often maximum denitrification rates occurring during winter/spring, associated with elevated $\mathrm{NO}_{3}{ }^{-}$concentrations within the water column, as a result of freshwater run-off (Jørgensen and Sørensen, 1988; Norwicki et al., 1997; Hietanen and Kuparinen, 2008). Coombabah Lake experiences a sub-tropical rainfall pattern, characterised by dry winter and wet summer seasons. However, the study period which coincided with El nino conditions, was characterised by a lack of typical intense summer rainfall events, resulting in smaller nitrate loads to the lagoon. During more typical summer conditions or La nina conditions, rainfall events and associated run-off, especially stormwater from surrounding urbanised areas and golf courses, would be expected to increase $\mathrm{NO}_{3}{ }^{-}$loads to the lagoon stimulating $\mathrm{NO}_{3}{ }^{-}$reduction rates. Water 
column $\mathrm{NO}_{3}{ }^{-}$concentrations have been shown to positively influence benthic nitrate reduction rates (Jørgensen and Sørensen, 1988). Consequently, nitrate reduction rates in the lagoon may exhibit a larger degree of seasonal variation under more typical rainfall regimes, especially as rainfall events would enhance $\mathrm{NO}_{3}{ }^{-}$availability preferentially during summer when temperatures, benthic metabolism and $\mathrm{NO}_{3}{ }^{-}$reduction rates are already high.

Total $\mathrm{NO}_{3}^{-}$reduction rates were significantly stimulated during light compared to dark incubations. This enhancement was presumably due to the photosynthetic stimulation of nitrification that occurred in the light increasing the availability of $\mathrm{NO}_{\mathrm{X}}$ in the sediment, as nitrification was the major source of $\mathrm{NO}_{\mathrm{X}}$ fuelling nitrate reduction. This diel pattern is the reverse of that typically recorded for MPB colonized sediments where competition between MPB and nitrifying and denitrifying bacteria for $\mathrm{NH}_{4}{ }^{+}$and $\mathrm{NO}_{\mathrm{X}}$ under illuminated conditions generally limits $\mathrm{NO}_{3}{ }^{-}$reduction rates (Risgaard-Petersen et al., 1994; Sundbäck et al., 2000). Although, similar diel denitrification patterns have been described in other shallow environments where oxygen production by MPB during periods of illumination enhanced nitrification rates, when ammonium availability was not a limiting factor (An and Joye, 2001).

The relative contributions of denitrification and DNRA to overall rates of $\mathrm{NO}_{3}{ }^{-}$reduction within a water body are ecologically significant, as they influence N-retention/loss dynamics (Nizzoli et al., 2006). During this study, DNRA was the dominant nitrate reduction pathway, supporting the conclusion that the lagoon retains and recycles rather than eliminates N. Several factors have been proposed to favour DNRA over denitrification, including high temperature, high ratios of labile organic carbon to $\mathrm{NO}_{3}{ }^{-}$(electron donor:electron acceptor), low nitrate availability, and reduced sulphidic sediment conditions (Nizzoli et al., 2006 and references therein). Tiedje (1988) suggested that DNRA is generally favoured in organically enriched, highly metabolic sediments. The lagoon data is in general agreement with this hypothesis, as the 
contribution of DNRA was greatest in the southern muddy lagoon sediments which are characterised by higher rates of benthic metabolism, greater organic matter and sulphide contents (Dunn et al., 2008; Dunn pers. obs.).

Nitrification was the dominant source of $\mathrm{NO}_{\mathrm{X}}$ for nitrate reduction processes in the lagoon sediments, with $D_{n}$ and DNRA $_{n}$ representing $\sim 90 \%$ of total denitrification and DNRA respectively. Coupling between nitrification and total $\mathrm{NO}_{3}{ }^{-}$reduction was greatest during autumn and lowest during winter, and varied between sites (site $1>4>2>3$ ). The degree of coupling between nitrification and nitrate reduction was higher during light compared to dark incubations indicating that MPB played a regulatory role. Microphytobenthos can influence denitrification of $\mathrm{NO}_{\mathrm{X}}$ produced by nitrification under both light and dark conditions (Risgaard-Petersen et al., 1994; Rysgaard et al., 1994). Typically, under dark conditions, MPB N-assimilation rates are low and increased $\mathrm{NH}_{4}^{+}$availability favours nitrification and therefore coupled nitrificationdenitrification if oxygen is not a limiting factor. Whereas under light conditions oxygen is relatively abundant but $\mathrm{N}$-assimilation by MPB decreases the availability of $\mathrm{NH}_{4}{ }^{+}$for nitrification and competes with nitrate reduction processes for $\mathrm{NO}_{\mathrm{X}}$ limiting rates of nitrification and nitrate reduction (Risgaard-Petersen et al., 1994; Rysgaard et al., 1994). However, in the sediments of Coombabah Lake where constant $\mathrm{NH}_{4}{ }^{+}$effluxes indicate that $\mathrm{NH}_{4}{ }^{+}$is always abundant in the sediment, oxygen would become the limiting factor for nitrification and this diel pattern would be reversed. Photosynthetic oxygen production by MPB would enhance oxygen availability and increase oxygen penetration into the sediment favouring coupled nitrification-denitrification. Conversely, under dark conditions oxygen availability and penetration depth would be reduced, and nitrification would be limited due to competition with heterotrophic bacteria for oxygen, and therefore nitrate production would limit rates of coupled nitrification-denitrification (Rysgaard et 
al., 1994; An and Joye, 2001). In this study rates of coupled nitrification-denitrification were stimulated on average by $5.6 \pm 3.1$-fold in the light. Similar stimulations of coupled nitrificationdenitrification by 2.1 to 22 -fold under light conditions were reported in the sub-tropical estuarine sediments of Galveston Bay (USA) associated with photosynthetic oxygen production by microalgae (An and Joye, 2001). Such increases demonstrate that enhancement of nitrification in sediments coupled to photosynthetic oxygen production by MPB can contribute strongly to diurnal patterns of denitrification.

Conversely, denitrification fuelled by nitrate diffusing from the water column was a minor process at all sites during all seasons in Coombabah Lake, presumably as a result of the low water column $\mathrm{NO}_{\mathrm{X}}$ concentrations which persisted throughout this study. However, under a more typical rainfall regime water column $\mathrm{NO}_{\mathrm{X}}$ concentrations would be expected to be enhanced during the summer wet season, increasing seasonal variation in denitrification rates, especially under dark conditions when reduced oxygen penetration in the absence of photosynthetic oxygen evolution would decrease the diffusional path length for $\mathrm{NO}_{\mathrm{X}}$ to the sediment denitrification zone, enhancing diffusion rates and thereby rates of denitrification (Risgaard-Petersen et al., 1994; Rysgaard et al., 1994).

Sediment denitrification efficiencies were generally low throughout the lagoon. As observed for sediments of Waquoit Bay (USA) (LaMontague et al., 2002), denitrification efficiencies in the lagoon sediments were significantly negatively correlated with $\mathrm{NH}_{4}{ }^{+}$efflux rates $(r=0.484, p$ $<0.05)$. Decreased denitrification efficiencies coinciding with increased $\mathrm{NH}_{4}{ }^{+}$efflux may reflect the content and degradation rates of organic matter within the sediments, as increased SOD for the mineralization of organic matter, would enhance oxygen limitation of nitrification and coupled nitrification-denitrification, leading to a greater proportion of remineralized nitrogen being recycled back to the overlying water column as $\mathrm{NH}_{4}{ }^{+}$. Additionally, as the organic matter 
loading increases, DNRA may become an increasingly more important sink for $\mathrm{NO}_{\mathrm{X}}$, again limiting denitrification (Tiedje, 1988; Eyre and Ferguson, 2002; Nizzoli et al., 2006). Thus, the low denitrification efficiencies within Coombabah Lake sediments are likely to result from the comparatively organic-rich sediments and continual strong SOD, with the lower efficiencies at sites 3 reflecting the increased organic matter content and higher SOD of the muddier southern sediments (Christensen et al., 2000; Eyre and Ferguson, 2002; Nizzoli et al., 2006).

Although no direct significant correlations were observed between sediment organic matter content and $\mathrm{NO}_{3}{ }^{-}$reduction rates, increased rates occurred at the southern muddy sites which were characterised by greater organic matter contents and higher SOD. Chl- $a$ concentrations were also shown to influence total nitrate reduction, denitrification and DNRA rates with significant ( $p$ $<0.05)$ correlations found with $\mathrm{D}_{\mathrm{w}}$ (light: $r=0.511$, dark: $\left.r=0.646\right), \mathrm{DNRA}_{\mathrm{w}}$ (light: $r=0.780$, dark: $r=0.711$ ), $\mathrm{DNRA}_{\mathrm{n}}$ (light: $\left.r=0.785\right), \mathrm{DNRA}_{\text {total }}$ (light: $r=0.785$ ), and total $\mathrm{NO}_{3}{ }^{-}$reduction rates (light: $p=0.778$ ). These correlations confirm the pivotal role that MPB played in regulating nitrogen cycling within the lagoon sediments.

\section{Conclusions}

This study investigated the seasonal sediment and water column characteristics, oxygen and DIN fluxes across the sediment-water interface, and rates of $\mathrm{NO}_{3}{ }^{-}$reduction within the intertidal sediments of sub-tropical Coombabah Lake. Seasonal sampling indicated that physico-chemical water column and sediment parameters demonstrated low seasonal variability. Conversely, sediment chl- $a$ concentrations, demonstrated a high degree of spatial and seasonal variability. Oxygen fluxes were consistently directed toward the sediment at all sampling sites, in all seasons during both light and dark incubations. This sustained SOD may contribute to the reported low 
dissolved oxygen saturation of the lagoon waters, which may have implications on its viability as a habitat for recreationally and economically targeted fish. The strongly heterotrophic sediments acted as a continual source of DIN to the water column under both light and dark conditions, with the greatest DIN effluxes occurring in the southern mud-dominated sediments. The exchange of solutes across the SWI varied over diel cycles reduced SOD and DIN effluxes under light conditions, due to the influence of the photosynthetic activity of MPB. Regenerated inorganic nutrients effluxing from the sediment appear to be assimilated by the surrounding mangroves and wetlands, rather than being exported. Therefore, future removal of these mangrove and wetland communities to accommodate expanding urban development, would threaten the trophic status of the lagoon and adjoining wetlands.

Nitrogen cycling processes exhibited only relatively minor seasonal variation within this subtropical lagoon compared to temperate systems which typically experience distinct, often strong seasonal patterns. The lack of seasonality within the lagoon may be at least partially attributable to both a limited seasonal temperature range and the lack of a typical summer wet season in the study year which resulted in low, relatively stable water column $\mathrm{NO}_{\mathrm{X}}$ concentrations. Photosynthetic oxygen production by MPB was the primary factor regulating nitrification within the sediments, and thereby nitrate reduction rates, as these were fuelled almost exclusively by nitrification. DNRA was the predominant nitrate reduction pathway, especially in the more metabolically active, muddy southern lagoon sediments.

\section{Acknowledgments}

The authors gratefully thank W. Bennett, D. Dunn, K. Dunn and D. Robertson for assistance with fieldwork and the anonymous reviewers for providing valuable comments to earlier versions 
of this manuscript. This work was supported by a grant from the Australian Research Council's Discovery Projects funding scheme (project number: DP0559935).

\section{References}

Ali, A., Lemckert, C.J., Dunn, R.J.K., 2010. Salt fluxes within a very shallow sub-tropical estuary. Journal of Coastal Research 26, 436-443.

An, S., Joye, S.B., 2001. Enhancement of coupled nitrification-denitrification by benthic photosynthesis in shallow estuarine sediments. Limnology and Oceanography 46, 62-74.

APHA, 1999. Standard Methods for the Examination of Water and Wastewater, $20^{\text {th }}$ Edition. American Public Health Association, Washington D.C., p.1325.

Barnes, J., Owens, N.J.P., 1998. Denitrification and nitrous oxide concentrations in the Humber Estuary, UK, and adjacent coastal zones. Marine Pollution Bulletin 37, 247-260.

Bartoli, M., Nizzoli, D., Viaroli, P., 2003. Microphytobenthos activity and fluxes at the sedimentwater interface: interactions and spatial variability. Aquatic Ecology 37, 341-349.

Berelson, W.M., Heggie, D., Longmore, A., Kilgore, T., Nicholson, G., Skyring, G., 1998. Benthic nutrient recycling in Port Phillip Bay, Australia. Estuarine, Coastal and Shelf Science 46, 917-934.

Berner, R.A., 1980. Early Diagenesis: A Theoretical Approach. Princeton University Press, Princeton, p.241.

Bouillon, S., Dahdouh-Guebas, F., Rao, A.V.S., Koedam, N., Dehairs, F., 2003. Sources of organic carbon in mangrove sediments: variability and possible ecological implications. Hydrobiologia 495, 33-39.

Burgin, A.J., Hamilton, S.K., 2007. Have we overemphasized the role of denitrification in aquatic 
ecosystems? A review of nitrate removal pathways. Frontiers in Ecology and the Environment 5, 89-96.

Christensen, P.B., Rysgaard, S., Sloth, N.P., Dalsgaard, T., Schwaerter, S., 2000. Sediment remineralization, nutrient fluxes, denitrification and dissimilatory nitrate reduction in an estuarine fjord with sea cage trout farms. Aquatic Microbial Ecology 21, 73-84.

Dalsgaard, T., Thamdrup, B., Canfield, D.E., 2005. Anaerobic ammonium oxidation (Anammox) in the marine environment. Research in Microbiology 156, 457-464.

Dong, L.F., Naqasima Sobey, M., Smith, C.J., Rusmana, I., Philips, W., Stott, A., Osborn, A.M., Nedwell, D.B., 2011. Dissimilatory nitrate reduction to ammonium, not denitrification or anammox, dominates benthic nitrate reduction in tropical estuaries. Limnology and Oceanography 56, 279-291.

Dunn, R.J.K., Lemckert, C.J., Teasdale, P.R., Welsh, D.T., 2007a. Distribution of nutrients in surface and sub-surface sediments of Coombabah Lake, southern Moreton Bay (Australia). Marine Pollution Bulletin 54, 606-614.

Dunn, R.J.K., Ali, A., Lemckert, C.J., Teasdale, P.R., Welsh, D.T., 2007b. Short-term variability of physico-chemical parameters and the estimated transport of filterable nutrients and chlorophyll- $a$ in the urbanised Coombabah Lake and Coombabah Creek system, southern Moreton Bay, Australia. Journal of Coastal Research 50, 1062-1068.

Dunn, R.J.K., Welsh, D.T., Lee, S.Y., Lemckert, C.J., Teasdale, P.R., Meziane, T., 2008. Investigating the distribution and sources of organic matter in surface sediment of Coombabah Lake (Australia) using elemental, isotopic and fatty acid biomarkers. Continental Shelf Research 28, 2535-2549.

Dunn, R.J.K., Welsh, D.T., Jordan, M.A., Teasdale, P.R., Lemckert, C.J., 2009. Influence of natural amphipod (Victoriopisa australiensis) (Chilton, 1923) population densities on benthic 
metabolism, nutrient fluxes, denitrification and DNRA in sub-tropical estuarine sediment. Hydrobiologia 628, 95-105.

Engelsen, A., Hulth, S., Pihl, L., Sundbäck, K., 2008. Benthic trophic status and nutrient fluxes in shallow-water sediments. Estuarine, Coastal Shelf Science 78, 783-795.

Eyre, B.D., Ferguson, A.J.P., 2002. Comparison of carbon production and decomposition, benthic nutrient fluxes and denitrification in seagrass, phytoplankton, benthic microalgae- and macroalgae-dominated warm-temperate Australian lagoons. Marine Ecology and Progress Series 229, 43-59.

Eyre, B.D, Maher, D., Oakes, J.M., Erler, D.V., Glasby, T.M., 2011. Differences in benthic metabolism, nutrient fluxes, and denitrification in Caulerpa taxifolia communities compared to uninvaded bare sediment and seagrass (Zostera capricorni) habitats. Limnology and Oceanography 56, 1737-1750.

Fenchel, T., King, G.M., Blackburn, T.H., 1998. Bacterial Biogeochemistry: The ecophysiology of mineral cycling. Academic Press, San Diego, p.307.

Gardner, W.S., McCarthy, M.J., An, S., Sobolev, D., Sell, K.S., Brock, D., 2006. Nitrogen fixation and dissimilatory nitrate reduction to ammonium (DNRA) support nitrogen dynamics in Texas estuaries. Limnology and Oceanography 51, 558-568.

Hietanen, S., Kuparinen, J., 2008. Seasonal and short-term variation in denitrification and anammox at a coastal station on the Gulf of Finland, Baltic Sea. Hydrobiologia 596, 67-77.

Jørgensen, K.S., Sørensen, J., 1988. Two annual maxima of nitrate reduction and denitrification in estuarine sediment (Norsminde Fjord, Denmark). Marine Ecology Progress Series 48, $147-$ 154.

Knight, J.M., Dale, P.E.R., Dunn, R.J.K., Broadbent, G.J., Lemckert, C.J., 2008. Patterns of tidal flushing within a mangrove forest: Lake Coombabah, South East Queensland Australia. 
Estuarine, Coastal and Shelf Science 76, 580-593.

LaMontagne, M.G., Astorga, V., Giblin, A.E., Valiela, I., 2002. Denitrification and the stoichiometry of nutrient regeneration in Waquoit Bay, Massachusetts. Estuaries 25, 272281.

Lorenzen, C.J., 1967. Determination of chlorophyll and pheo-pigments: spectrophotometric equations. Limnology and Oceanography 12, 343-346.

Molnar, N., Welsh, D.T., Marchand, C., Deborde, J., Meziane, T. 2012 (In Press). Impacts of shrimp farm effluents on water quality, benthic metabolism and $\mathrm{N}$-dynamics in a mangrove forest (New Caledonia). Estuarine Coastal Shelf Science.

Nielsen, L.P., 1992. Denitrification in sediment determined from nitrogen isotope pairing. FEMS Microbiology Ecology 86, 357-362.

Nizzoli, D., Welsh, D.T., Fano, E.A., Viaroli, P., 2006. Impact of clam and mussel farming on benthic metabolism and nitrogen cycling, with emphasis on nitrate reduction pathways. Marine Ecology and Progress Series 315, 151-165.

Norwicki, B.L., Kelly, J.R., Requintina, E., Keuren, D.V., 1997. Nitrogen losses through sediment denitrification in Boston Harbor and Massachusetts Bay. Estuaries 20, 626-639.

Pagès, A., Teasdale, P.R., Robertson, D., Bennett, W.W., Shäfer, J., Welsh, D.T., 2011. Representative measurement of reactive phosphate distributions and co-distributed iron(II) and sulfide in seagrass sediment porewaters. Chemosphere 85, 1256-1261.

Quinn, G.P., Keough, M.J., 2002. Experimental design and data analysis for biologists. Cambridge University Press, United Kingdom, p.556.

Risgaard-Petersen, N., Rysgaard, S., Nielsen, L.P., Revsbech, N.P., 1994. Diurnal variation of denitrification and nitrification in sediments colonized by benthic microphytes. Limnology and Oceanography 39, 573-579. 
Risgaard-Petersen, N., Rysgaard, S., 1995. Nitrate reduction in sediments and waterlogged soil measured by ${ }^{15} \mathrm{~N}$ techniques. In: Alef K, Nannipieri PS (Eds.) Methods in Applied Soil Microbiology and Biochemistry. Academic Press, London, pp.287-295.

Risgaard-Petersen, N., Nielsen, L.P., Rysgaard, S., Dalsgaard, T., Meyer, R.L., 2003. Application of the isotope pairing technique in sediments where anammox and denitrification coexist. Limnology and Oceanography: Methods 1, 63-73.

Robertson, A.I., Phillips, M.J., 1995. Mangrove as filters of shrimp pond effluent: predictions and biogeochemical research needs. Hydrobiologia 295, 311-321.

Robertson, D., Teasdale, P.R., Welsh, D.T., 2008. A novel gel-based technique for the twodimensional determination of iron (II) and sulfide in sediment. Limnology and Oceanography: Methods 6, 502-512.

Robertson, D., Welsh, D.T., Teasdale, P.R., 2009. Investigating biogenic heterogeneity in coastal sediments with two-dimensional measurements of iron (II) and sulphide. Environmental Chemistry 6, 60-69.

Rysgaard, S., Risgaard-Petersen, N., Sloth, N.P., Jensen, K., Nielsen, P.L. 1994. Oxygen regulation of nitrification and denitrification in sediments. Limnology and Oceanography 39, $1643-1652$.

Rysgaard, S., Christensen, P.B., Nielsen, L.P., 1995. Seasonal variation in nitrification and denitrification in estuarine sediment colonized by benthic microalgae and bioturbating infauna. Marine Ecology Progress Series 126, 111-121.

Sakamaki, T., Nishimura, O., Sudo, R., 2006. Tidal time-scale variation in nutrient flux across the sediment-water interface of an estuarine tidal flat. Estuarine, Coastal and Shelf Science $67,653-663$.

Sandulli, R., Pinckney, J., 1999. Patch sizes and spatial patterns of meiobenthic copepods and 
benthic microalgae in sandy sediments: a microscale approach. Journal of Sea Research 41, $179-187$.

Spilmont, N., Migne, A., Seuront, L., Davoult, D., 2007. Short-term variability of intertidal community production during emersion and the implication in annual budget calculation. Marine Ecology Progress Series 333, 95-101.

Spilmont, N., Seuront, L., Meziane, T., Welsh, D.T., 2011. There's more to the picture than meets the eye: sampling microphytobenthos in a heterogenous environment. Estuarine, Coastal and Shelf Science 95, 470-476.

Sundbäck, K., Enoksson, V., Granéli, W., Pettersson, K., 1991. Influence of sublittoral microphytobenthos on the oxygen and nutrient flux between sediment and water: a laboratory continuous-flow study. Marine Ecology and Progress Series 74, 263-279.

Sundbäck, K., Miles, A., Göransson, E., 2000. Nitrogen fluxes, denitrification and the role of microphytobenthos in microtidal shallow-water sediments: an annual study. Marine Ecology and Progress Series 200, 59-76.

Thornton, D.C.O., Dong, L.F., Underwood, G.J.C., Nedwell, D.B., 2007. Sediment-water inorganic nutrient exchange and nitrogen budgets in the Colne Estuary, UK. Marine Ecology and Progress Series 337, 63-77.

Tiedje, J.M., 1988. Ecology of denitrification and dissimilatory nitrate reduction to ammonium. In: Zehnder, A.J.B. (Ed.) Biology of Anaerobic Microorganisms. Wiley, New York, pp.179224.

Viaroli, P., Christian, R.R., 2003. Description of trophic status, hyperautotrophy and dystrophy of a coastal lagoon through a potential oxygen production and consumption index-TOSI: Trophic Oxygen Status Index. Ecological Indicators 3, 237-250.

Viaroli, P., Bartoli, M., Giordani, G., Magni, P., Welsh, D.T., 2004. Biogeochemical indicators as 
tools for assessing sediment quality/vulnerability in transitional aquatic ecosystems. Aquatic Conservation: Marine and Freshwater Ecosystems 14, S19-S29.

Vitousek, P.M., Aber, J.D., Howarth, R.W., Likens, G.E., Matson, P.A., Schindler, D.W., Schlesinger, W.H., Tilman, D.G., 1997. Human alteration of the global nitrogen cycle: Sources and consequences. Ecological Applications 7, 737-750.

Waltham, N., 2002. Health of the Gold Coast Waterways. Gold Coast City Council, Australia. $180 \mathrm{p}$.

Welsh, D.T., Bartoli, M., Nizzoli, D., Castaldelli, G., Riou, S.A., Viaroli, P., 2000. Denitrification, nitrogen fixation, community primary productivity and inorganic- $\mathrm{N}$ and oxygen fluxes in an intertidal Zostera noltii meadow. Marine Ecology Progress Series 208, $65-77$.

Wenzhofer, F., Glud, R.N., 2004. Small-scale spatial and temporal variability in coastal benthic $\mathrm{O}_{2}$ dynamics: Effects of fauna activity. Limnology and Oceanography 49, 1471-1481.

Wong, Y.S., Tam, N.F.Y., Lan, C.Y., 1997. Mangrove wetlands as wastewater treatment facility: a field trial. Hydrobiologia 352, 49-59. 


\section{Tables}

Table 1. Seasonal water column dissolved inorganic nutrient and physico-chemical values. All data are expressed as mean values \pm one standard deviation.

\begin{tabular}{lcccccccc}
\hline \multirow{2}{*}{ Season } & \multicolumn{3}{c}{ Dissolved inorganic nutrients } & \multicolumn{3}{c}{ Physico-chemical parameters } \\
\cline { 2 - 9 } & $\begin{array}{c}\mathrm{NO}_{2}{ }^{-} \\
(\mu \mathrm{M})\end{array}$ & $\begin{array}{c}\mathrm{NO}_{3}{ }^{-} \\
(\mu \mathrm{M})\end{array}$ & $\begin{array}{c}\mathrm{NH}_{4}{ }^{+} \\
(\mu \mathrm{M})\end{array}$ & $\begin{array}{c}\mathrm{PO}_{4}{ }^{3-} \\
(\mu \mathrm{M})\end{array}$ & Salinity & $\mathrm{pH}$ & $\begin{array}{c}\text { Temp. } \\
\left({ }^{\circ} \mathrm{C}\right)\end{array}$ & $\begin{array}{c}\text { Chl- } a \\
\left(\mu \mathrm{g} \mathrm{l} \mathrm{l}^{-1}\right)\end{array}$ \\
\hline Winter & $2.4 \pm 1.4$ & $6.8 \pm 5.3$ & $37.2 \pm 14.8$ & $2.0 \pm 0.6$ & $33.1 \pm 0.2$ & $8.1 \pm 0.4$ & $18.4 \pm 0.5$ & $1.1 \pm 0.4$ \\
Spring & $1.9 \pm 1.6$ & $4.8 \pm 4.7$ & $34.2 \pm 19.8$ & $5.2 \pm 2.7$ & $32.1 \pm 0.1$ & $7.9 \pm 0.6$ & $21.3 \pm 0.3$ & $1.4 \pm 0.2$ \\
Summer & $1.5 \pm 0.4$ & $13.9 \pm 3.9$ & $41.0 \pm 16.3$ & $4.8 \pm 1.1$ & $33.4 \pm 0.2$ & $7.9 \pm 0.9$ & $25.7 \pm 0.8$ & $1.8 \pm 0.8$ \\
Autumn & $1.5 \pm 0.9$ & $8.6 \pm 3.7$ & $38.5 \pm 15.0$ & $4.1 \pm 1.2$ & $33.6 \pm 0.2$ & $8.0 \pm 0.2$ & $21.6 \pm 0.7$ & $1.4 \pm 0.3$ \\
\hline
\end{tabular}


Table 2. Summarised results of the 3-way ANOVA (light condition, season and site fixed) analysis of sediment water column oxygen and inorganic nitrogen fluxes. Significant outcomes are shown in bold.

\begin{tabular}{|c|c|c|c|c|c|c|}
\hline & & Flux & DIN & $\mathrm{NH}_{4}^{+}$ & $\mathrm{NO}_{\mathrm{X}}$ & $\mathrm{O}_{2}$ \\
\hline Source & $d f$ & & & $p$ & & \\
\hline Light & 1 & & 0.001 & 0.001 & 0.534 & 0.001 \\
\hline Site & 3 & & 0.001 & 0.001 & 0.006 & 0.001 \\
\hline Season & 3 & & 0.001 & 0.001 & 0.407 & 0.001 \\
\hline Light*Site & 3 & & 0.983 & 0.588 & 0.903 & 0.036 \\
\hline Light*Season & 3 & & 0.142 & 0.125 & 0.963 & 0.076 \\
\hline Site*Season & 9 & & 0.001 & 0.001 & 0.560 & $\mathbf{0 . 0 2 7}$ \\
\hline Light*Site*Season & 9 & & 0.549 & 0.177 & 0.999 & 0.652 \\
\hline
\end{tabular}


Table 3. Pearson correlation coefficients for site specific seasonal mean light and dark oxygen fluxes, and surface sediment $\mathrm{LOI}_{550}$, chl- $a$ and inorganic nutrient contents $(n=16, *=$ correlation significant at the 0.05 level (2-tailed), ** = correlation significant at the 0.01 level (2-tailed)). Significant outcomes are shown in bold.

\begin{tabular}{llllllll}
\hline & & & \multicolumn{5}{c}{ Flux } \\
\cline { 5 - 7 } & & LOI $_{550}{ }^{\diamond}$ & $\mathrm{Chl}-a$ & $\mathrm{NO}_{3}{ }^{-}$ & $\mathrm{NO}_{\mathrm{X}}$ & $\mathrm{NH}_{4}{ }^{+}$ & $\mathrm{DIN}$ \\
\hline Light & & & & & & & \\
$\mathrm{O}_{2}$ Flux & $r$ & 0.170 & 0.284 & 0.366 & 0.454 & 0.347 & 0.374 \\
& $p$ & 0.530 & 0.286 & 0.163 & 0.077 & 0.188 & 0.154 \\
Dark & & & & & & & \\
$\mathrm{O}_{2}$ Flux & $r$ & $-0.619^{* *}$ & $-0.554^{*}$ & $-0.736^{* *}$ & $-0.718^{* *}$ & $-0.677^{* *}$ & $-0.714^{* *}$ \\
& $p$ & $\mathbf{0 . 0 1 1}$ & $\mathbf{0 . 0 2 6}$ & $\mathbf{0 . 0 0 1}$ & $\mathbf{0 . 0 0 2}$ & $\mathbf{0 . 0 0 4}$ & $\mathbf{0 . 0 0 2}$ \\
\hline
\end{tabular}

${ }^{\nabla}$ Mean value for surface sediment $0-2 \mathrm{~cm}$ depth horizon 
Table 4. Pearson correlation coefficients for site specific seasonal mean light and dark sediment-water column inorganic nitrogen effluxes $(n=16)$ and sediment $\mathrm{LOI}_{550}$ and chl$a$ contents $(n=16, *=$ correlation significant at the 0.05 level $(2$-tailed $), * *=$ correlation significant at the 0.01 level (2-tailed)). Significant outcomes are shown in bold.

\begin{tabular}{|c|c|c|c|c|c|}
\hline & & \multicolumn{2}{|c|}{ Light } & \multicolumn{2}{|c|}{ Dark } \\
\hline & & $\mathrm{LOI}_{550}{ }^{+}$ & Chl- $a$ & $\mathrm{LOI}_{550}{ }^{+}$ & Chl- $a$ \\
\hline \multirow[t]{2}{*}{$\mathrm{NO}_{3}^{-}$} & $r$ & $0.520 *$ & $0.734 * *$ & $0.500 *$ & $0.641 * *$ \\
\hline & $p$ & 0.039 & 0.001 & 0.049 & 0.007 \\
\hline \multirow[t]{2}{*}{$\mathrm{NO}_{\mathrm{X}}$} & $r$ & $0.514 *$ & $0.594 *$ & $0.525 *$ & $0.566^{*}$ \\
\hline & $p$ & 0.046 & 0.015 & 0.037 & 0.022 \\
\hline \multirow[t]{2}{*}{$\mathrm{NH}_{4}^{+}$} & $r$ & 0.423 & 0.063 & 0.376 & $0.577 *$ \\
\hline & $p$ & 0.103 & 0.817 & 0.152 & 0.019 \\
\hline \multirow[t]{2}{*}{ DIN } & $r$ & $0.499 *$ & 0.486 & 0.408 & $0.605^{*}$ \\
\hline & $p$ & 0.049 & 0.056 & 0.117 & 0.013 \\
\hline
\end{tabular}

${ }^{+}$Mean content for the surface sediment 0-4 cm depth horizon 
Table 5. Summarised results of the three-way ANOVA (light condition, season and site fixed) analysis of total nitrate reduction,

denitrification, DNRA and nitrification rates, and the coupling between nitrification/denitrification (\% coupling) and \% denitrification efficiency (denitrification/DIN efflux + denitrification $\times 100)$. Significant outcomes are shown in bold.

\begin{tabular}{lcccccc}
\hline & \multicolumn{2}{c}{$\begin{array}{c}\text { Total } \\
\text { Nitrate } \\
\text { Reduction }\end{array}$} & Denitrification & DNRA & Nitrification & $\begin{array}{c}\text { Coupling } \\
\text { Efficiency }(\%)\end{array}$ \\
\hline Source & $d f$ & & & & $p$ \\
Light & 1 & $\mathbf{0 . 0 0 7}$ & $\mathbf{0 . 0 0 0}$ & $\mathbf{0 . 0 0 1}$ & 0.090 & $\mathbf{0 . 0 2 5}$ \\
Site & 3 & $\mathbf{0 . 0 0 2}$ & $\mathbf{0 . 0 0 0}$ & 0.252 & $\mathbf{0 . 0 0 0}$ & $\mathbf{0 . 0 0 8}$ \\
Season & 3 & $\mathbf{0 . 0 1 0}$ & $\mathbf{0 . 0 0 0}$ & 0.211 & $\mathbf{0 . 0 1 4}$ & 0.086 \\
Light*Site & 3 & 0.614 & 0.975 & 0.502 & 0.680 & 0.826 \\
Light*Season & 3 & 0.923 & 0.910 & 0.844 & 0.995 & 0.519 \\
Site*Season & 9 & 0.065 & $\mathbf{0 . 0 2 8}$ & $\mathbf{0 . 0 3 8}$ & 0.210 & 0.949 \\
Light*Site*Season & 9 & 0.987 & 0.895 & 0.992 & 0.971 & 0.532 \\
\hline
\end{tabular}




\section{Figure legends}

Figure 1. Map of (a) Australia, showing (b) the southern region of Moreton Bay and (c) sampling sites within Coombabah Lake.

Figure 2. Seasonal surface $(0-1 \mathrm{~cm})$ chlorophyll- $a$ concentrations at each study site. Data are mean values and error bars show the standard deviation of the mean concentration ( $n$ =3). Note: a different y-axis scale has been used for site 4 .

Figure 3. Seasonal mean sediment-water column oxygen fluxes during (a) light and (b) dark incubations (negative values indicate consumption and flux of oxygen into the sediment) and (c) gross productivity $\left(\Delta \mathrm{O}_{2}\right)$ at each study site. Data are mean values and error bars show the standard deviation of the mean flux/productivity $(n=3)$.

Figure 4. Seasonal sediment-water column dissolved DIN, $\mathrm{NH}_{4}{ }^{+}$and $\mathrm{NO}_{\mathrm{X}}\left(\mathrm{NO}_{3}{ }^{-}\right.$white portion of bar; $\mathrm{NO}_{2}^{-}$grey portion of bar), fluxes during light and dark incubations (positive values indicate efflux of the solute out of the sediment) at each study site. Data are mean values and error bars show the standard deviation of the mean flux $(n=3)$.

Figure 5. Seasonal rates of denitrification divided into $D_{w}$ (grey portion of bar) and $D_{n}$ (white portion of bar), DNRA divided into $\mathrm{DNRA}_{\mathrm{w}}$ (grey portion of bar) and $\mathrm{DNRA}_{\mathrm{n}}$ (white portion of bar) and total nitrate reduction divided into total DNRA (grey portion of bar) and total denitrification (white portion of bar) during light and dark incubations at 
each study site. Data are mean values and error bars show the standard deviation of the mean rate $(n=3)$. Please note difference in y-axis scale for site 4 .

Figure 6. Correlations between site specific seasonal mean (a) sediment chlorophyll- $a$ content and $\Delta \mathrm{O}_{2}$, (b) sediment chlorophyll-a content and $\Delta \mathrm{NH}_{4}{ }^{+}$and (c) $\Delta \mathrm{O}_{2}$ and $\Delta \mathrm{NH}_{4}{ }^{+}$ $\left(\Delta \mathrm{O}_{2}=\right.$ light - dark $\mathrm{O}_{2}$ flux and $\Delta \mathrm{NH}_{4}{ }^{+}=$dark - light $\mathrm{NH}_{4}{ }^{+}$flux $)(n=16)$. All correlations were significant at the $\mathrm{p}<0.05$ level. 


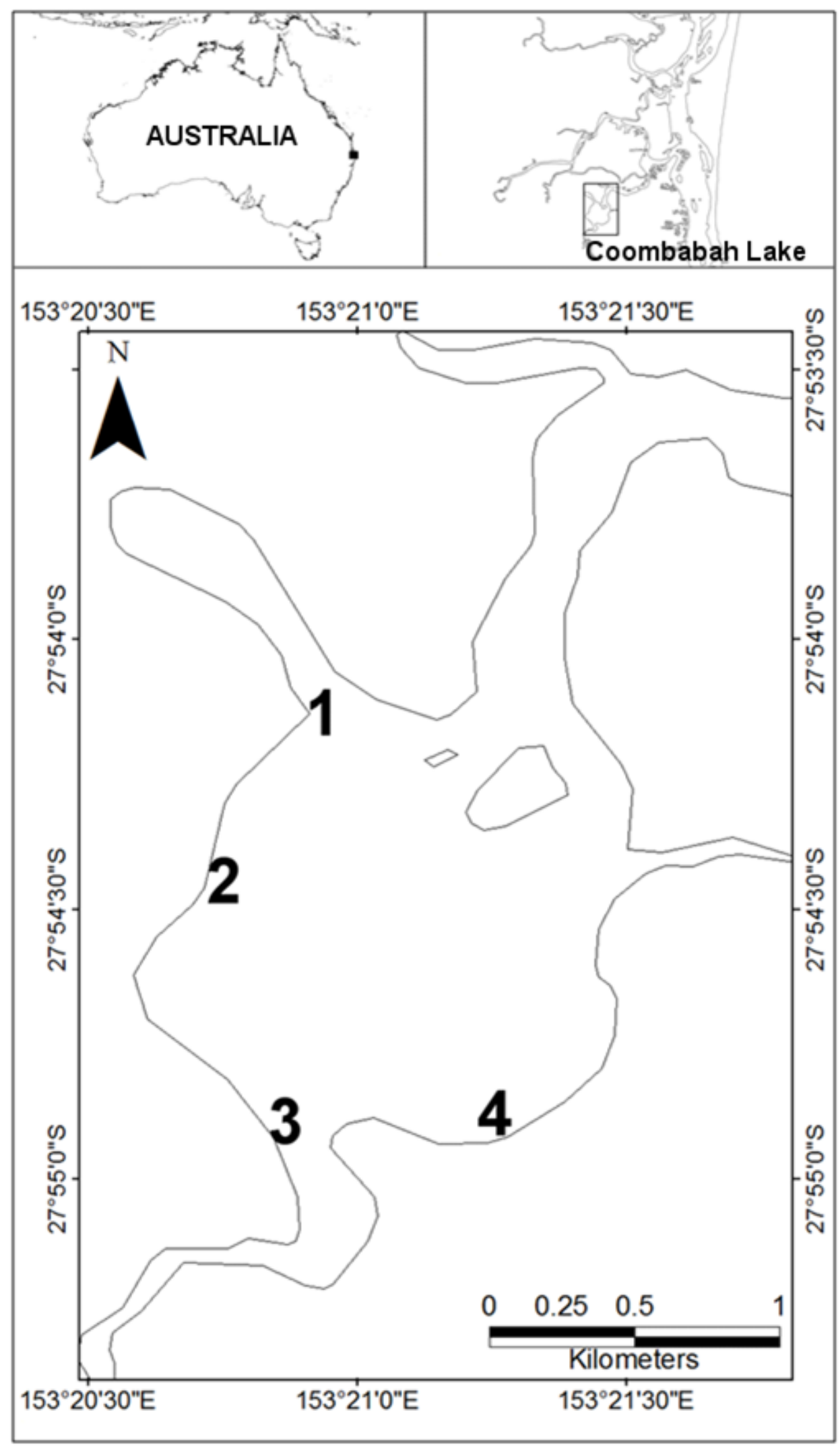

Fig. 1 


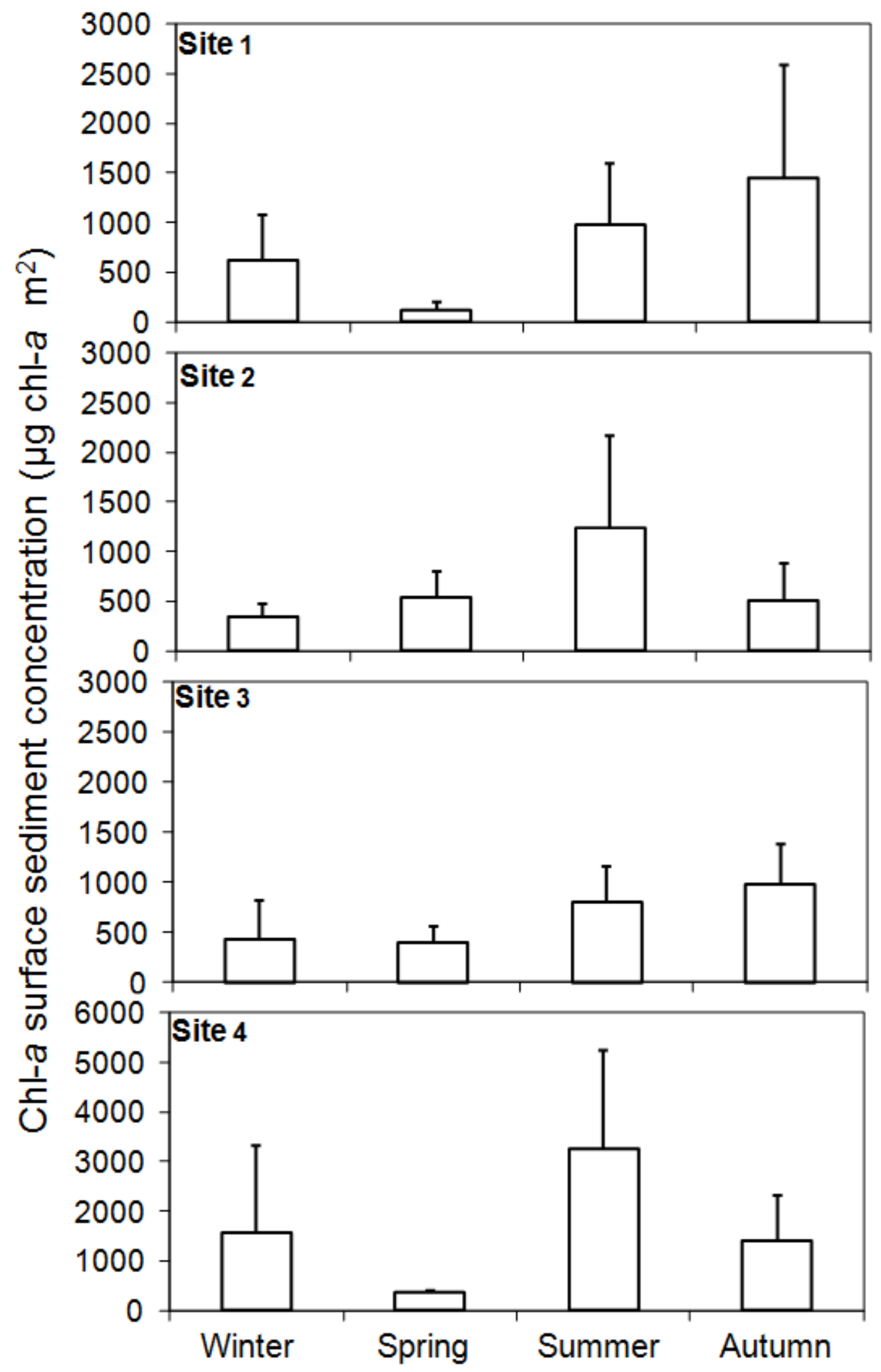

Fig. 2 


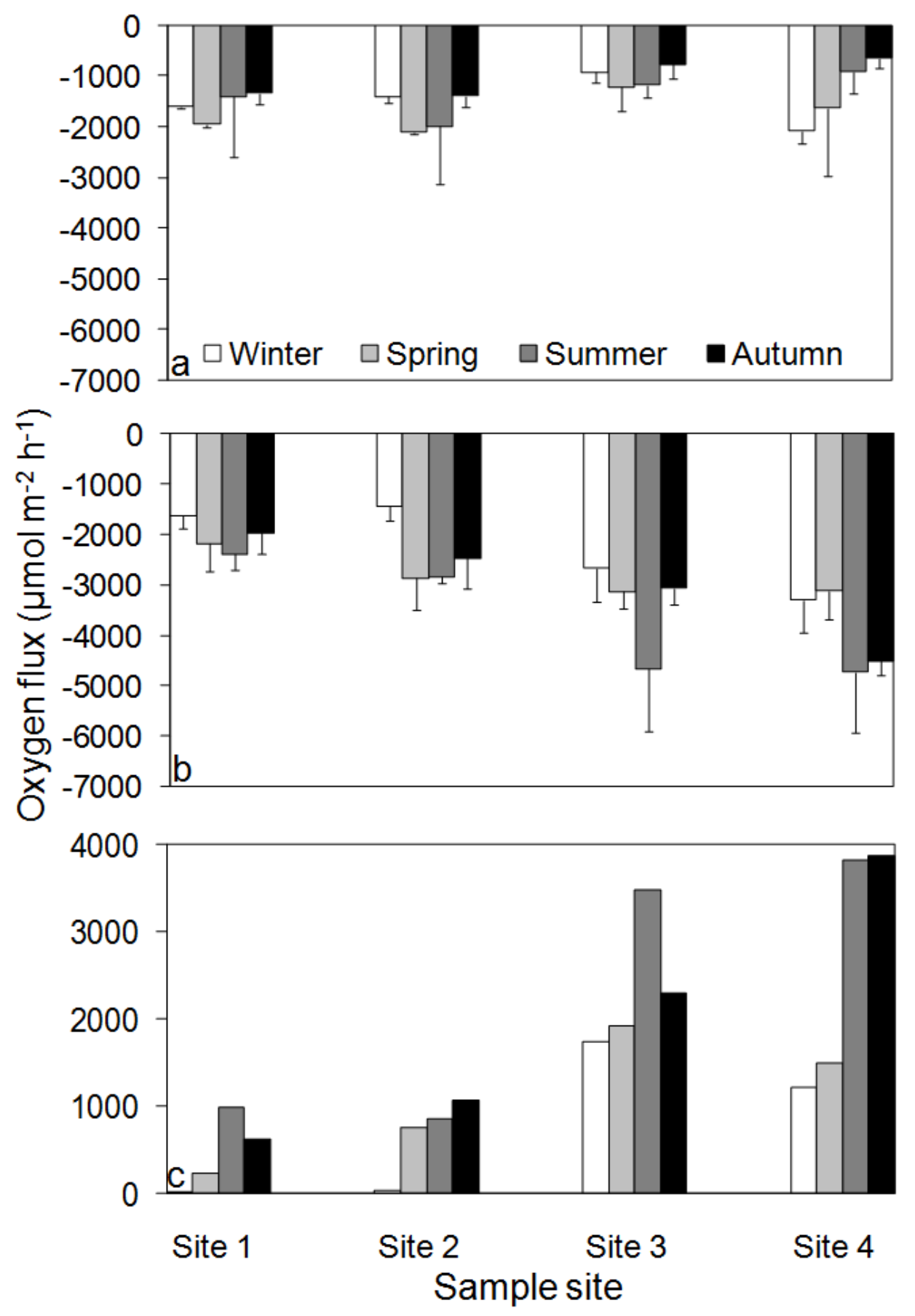

Fig. 3 


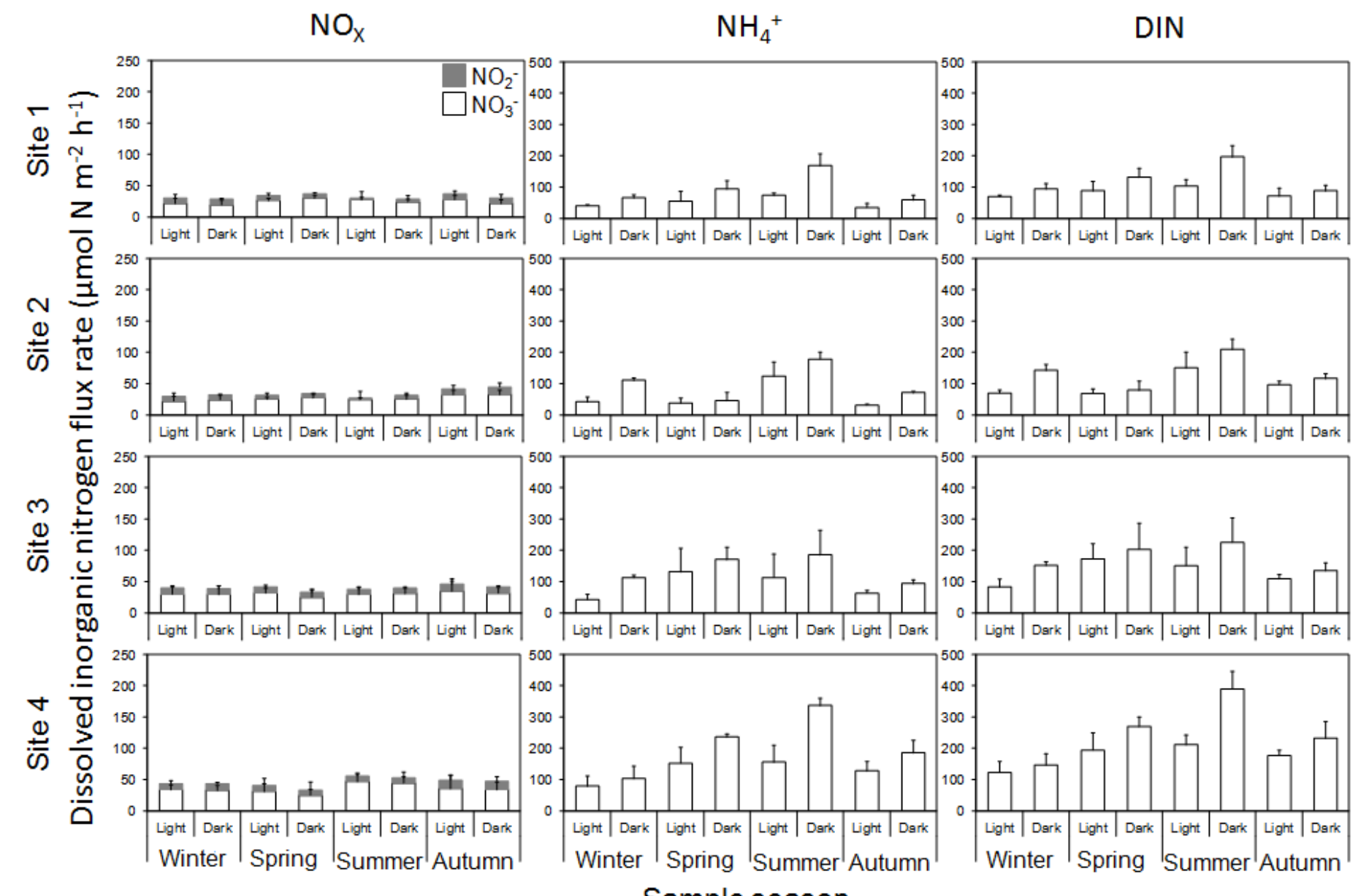

Sample season

Fig. 4 

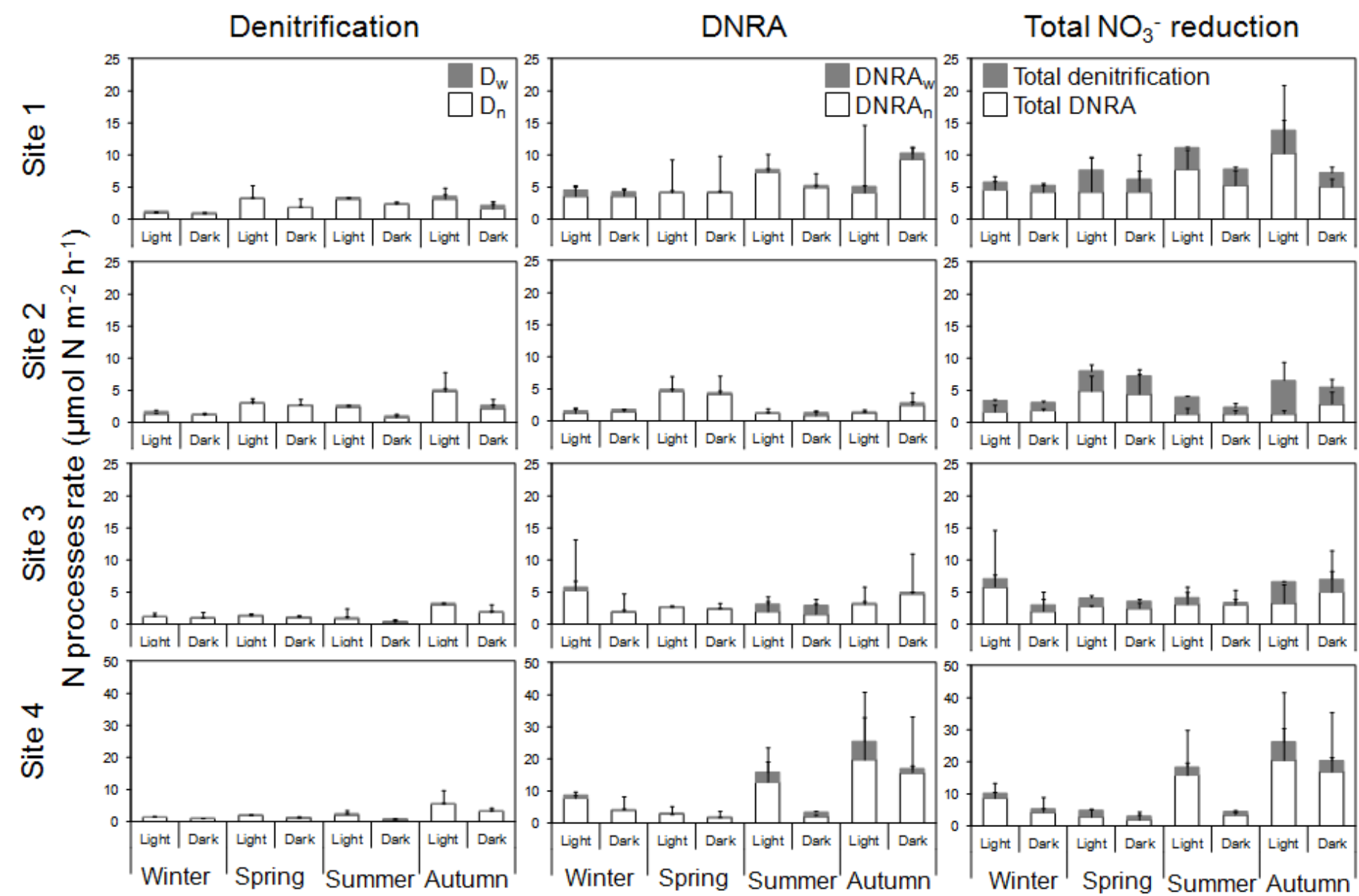

\section{Sample season}

Fig. 5 

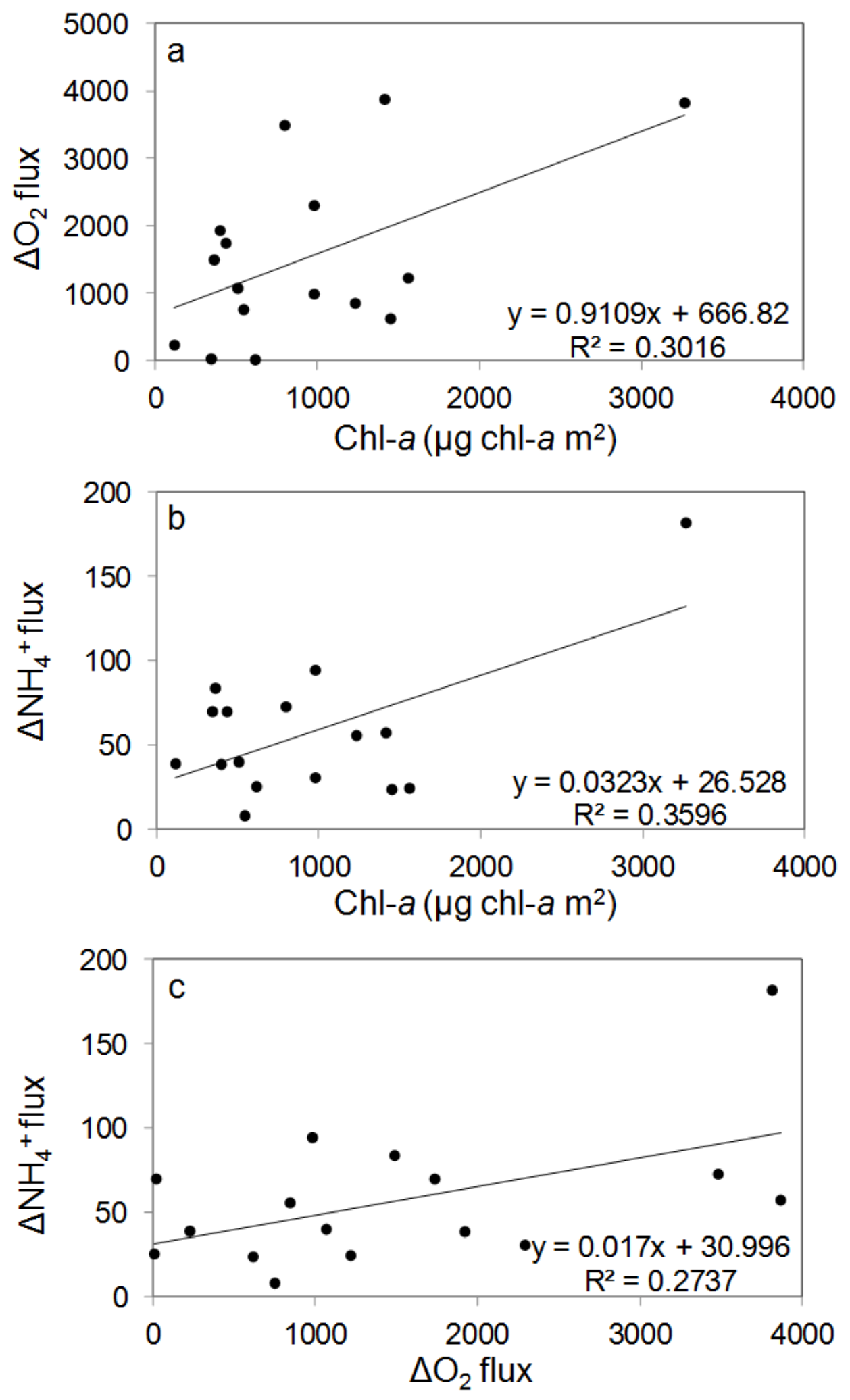

Fig. 6 